\title{
Impact of Extracurricular Activities on Academic Performance of Students at Secondary Level
}

\author{
Shabiha Anjum ${ }^{1}$ \\ 1, Bahauddin Zikariya University, Pakistan \\ Corresponding author : shabiha.anjum.sa@gmail.com
}

\section{AR T I C L E I N F O}

\section{Article history: \\ Received may 2021 \\ Revised june 2021 \\ Accepted july 2021}

\section{Keywords:}

extracurricular activities

academic performance

secondary level

\begin{abstract}
A B S T R A C T
The present study aims to observe the impact of extracurricular activities on the academic performance of students at the secondary level in Multan city. All the students at the secondary level in the public sector of Multan city are the population of this study. Three hundred student's 9th and 10th classes from (two) secondary schools from Multan city were selected. For this study, the researcher uses a simple random sampling technique. A total of 30 survey questions were developed based on Likert-scale type statement options (SA, A, N, DA, SDA), keeping in mind the objective of the study. The data were tabulated and analyzed by using descriptive statistical techniques. The MS-Excel is used for the descriptive analysis of the data. The study concluded that there is a severe need for the introduction of extracurricular activities, orientation programs for the students of secondary level. Extracurricular activities have a positive influence on students' life by improving their behavior, academic performance, better exam scores, more regular class attendance, a better self-image, due to these aspects which makes the students life more successful. Finally, the study suggests that Government should support the introduction of extracurricular activities in all secondary schools, allocate special funds, appoint special trainers/teachers, and fix their pay equal to other subject teachers.

(C) IJAGC 2021, All right reserved ISSN: 2722-2365 (Online) 2722-2357 (Print)
\end{abstract}

\section{Introduction}

Extracurricular activities are defined as those activities which are not the components of the academic curriculum but an important part of the educational environment. Extracurricular activities comprise sports, singing, music, debate, dance, drama, social services, etc. Schools can play a significant role by transmitting the energy of both normal as well as physically challenged students into a positive direction of personality development through extracurricular activities.

Extracurricular activities play an important role for develop the skills of the students. It makes a student think critically, managing time well, and competently in terms of intelligence. It also helps the student to achieve social goals and maturity. Having social 
maturity helps the student to interact and make better relationships with the people in the community (Himelfarb, Lac \& Baharav, 2013). The role and effects of ECA on the student's life in school days are very strong. From his study, ECA is beneficial to play the positive role of a student in school. It improves the behavior and the academic performance of the students in school life (Singh \& Imam, 2012).

Extracurricular framework, students can choose activities, which can be classified as physical activities, educational activities, and social activities. Physical activities include team activities (i.e., joining a sports team like a football team or cricket team) or individual activities (i.e., self-defense club-like taekwondo or joining charity deeds). Furthermore, physical programs can be compulsory where every student has to join and engage in one physical activity (Gardner et al, 2008).

Extracurricular activities (ECA) have an important role in today's high school programs. When one considers a large number of activities available, one realizes the variety of the programs. Included in ECA are athletics, publication, student groups, fine arts, academic clubs, and many more. There is a huge amount of research focused on studying the relationship between student involvement in activities and student academic achievement. Although a positive relation has been shown in many of these studies, there is still a competitive battle among educators concerning the need for ECA. Research findings suggest that professional school counselors, school officials, and community agency personnel can collaborate and use extracurricular activities to help target the academic achievement of other uninvolved or off-track students (Howard \& Ziomek-Daigle, 2009)

Activities were introduced to enable students to explore and build their learning on Extra-curricular activities can affect students learning and academic performance because of time management skills (Gilman, 2004). Students who engage in extra-curricular activities have difficulty managing their time. For instance, activities such as basketball and volleyball require a lot of energy and dedication. But it is very useful for developing the mental health and personality of the students. Activities may take more than several hours which leaves students with insufficient time to complete their homework or to study for exams. But the active mind teaches the students how to manage their time for both studies and extracurricular activities.

The Schools have always tried to increase their achievement results, but the current economic situation in our country is forcing school levels to make tough economic decisions. Currently, the economy of our country is forcing schools to reduce school budgets, reduce the teacher workforce, reduce student activities, and cut or eliminate non-essential activities like extracurricular activities (Slater \& Tiggemann, 2014).

Lunenburg stated in his article that "Extracurricular activities serve the same goals and functions as the required and elective courses in the curriculum. However, they provide experiences that are not included in formal courses of study. They allow students to apply the knowledge that they have learned in other classes and acquire concepts of democratic life (Lunnenburg, 2010). Extracurricular activities have many positive impacts on education. These positive effects are students' better behavior, good grades, personality development which makes the students more successful and socially strong adults.

\section{Method}

The questionnaire was personally developed by the researcher after the studying of relevant review of literature and material that is available in, books, journals, articles, library, 
internet and doing the detailed discussion with the supervisor of this research. For this purpose questionnaire was developed as a research tool. A questionnaire as a quantitative technique was used for data collection. The survey questions were developed based on Likertscale type statement options (SA, A, N, D, SD), keeping in mind the objective of the study. The data were tabulated and analyzed by using descriptive statistical techniques. The Micro SoftExcel is used for the descriptive analysis of the data. For descriptive statistical analysis mean, median and standard deviation were calculated for each statement

\section{Findings and Discussion}

Findings

According to Eccles (2003) that those students who participated in intentional, schoolbased extracurricular activities perform better in schools life. This happens due to ECA facilitates better Human interaction skills and more passionate association to one's school. Participation in out-of-school activities helps develop students' brains contributing to better mental health. It also helps them fortify their academic performance for a long period. Extracurricular activities also reduce behavioral and disciplinary problems.

Expressed the need for students to participate in school activities indicating that these activities were necessary to prepare adolescents for a more leisure world, due to a shortened workweek. In essence, extracurricular activities as preparation for adult social life (Slater \& Tiggemann, 2014).

The research on athletic participation in extracurricular activities has been extensive. A positive association between academic performance and athletic participation. In a study conducted in 24 Iowa schools, the author found varsity football participants to have a higher grade point average than non-participatory classmates. However, as in most studies, the results were not controlled for other intervening variables (Mangino, 2014).

There is always an argument that extracurricular activities are not so much important in a child's life. For development, extra activities are also most important in a student's life. Students are pressurized during exams and they have performance pressure too of gaining good grades. In such conditions, there is a need for some extra activities. You cannot force a student to just read books and become intelligent. Extra activities are also important for the overall development of students. Sometimes when a school offers sports and extra activities parents do not allow their children to participate. Some students also feel that they do not need the activities, all they need is to concentrate on their books in many schools teachers have to convince parents to permit their children to participate in activities. Parents feel that extra activities will distract their children from their studies. Co-curricular activities are important just as academics. When a student is made to do academics and co-curricular activities then only a well-rounded development of the student is done Students have lots of activities to choose from. Cultural activities, sports activities, competitions, house on duties, and a lot more. Some students are even interested in more than one activity and they do participate in both keeping in mind their academics.

1. The classroom teaching-learning environment gets strengthens by extracurricular activities.

2. Extracurricular activities enable the students to express themselves freely. Inculcate the values of co-operation. 
3. It is a means of developing skills and competence. Different extracurricular activities have their significance i.e., Debate helps to generate ideas and giving reasons and counter-reasons (Ramey, Lawford \& Rose-Krasnor,2019).

The advantages of youngsters take part in extracurricular activities and their effects on academic achievement (Kanar \& Bouckenooghe, 2021). Students participating in extracurricular activities possess high grades, higher standardized extracurricular activities were less able to utilize drugs and alcohol, give up on school, misbehave, and commit crime at the school level. test results, excellent educational adaptation, more attended school, higher self-trust, and good personality development. In furthermore, it was observed that the participating young people were fewer chances to utilize drugs and alcohol, give up schools, misbehave with others and commit crimes at the school level.

Literature supports participation in extracurricular activities as a way to encourage healthy development options. Time-consuming extracurricular activities can be seen as an obstacle to academic success. Due to pressure from parents and students themselves, this can be used as an excuse to abandon extracurricular activities. Consultants may want to find a balance between scientists and activities. There are many reasons why the role of the school counselor is important to integrate both academic and extracurricular activities.

The survey results of this study that data collected and analyzed through descriptive statistics are presented below. A brief discussion regarding the study has been presented. The method of percentage was used to analyze the data and tabular format was used to present the data. The finding of the analysis of the statement was as under:

Table 1.

\section{Analysis of Instrument}

\begin{tabular}{|c|c|c|c|c|c|c|c|c|}
\hline Statements & SD\% & $\mathrm{D} \%$ & $\mathrm{~N} \%$ & $\mathrm{~A} \%$ & SA\% & Mean & Mode & $\begin{array}{l}\text { Sad. } \\
\text { Dev }\end{array}$ \\
\hline $\begin{array}{l}\text { I feel improvement in my } \\
\text { communication skills due to ECA }\end{array}$ & 0 & 0 & 6.0 & 69.1 & 24.9 & 4.19 & 4.00 & 0.52 \\
\hline $\begin{array}{l}\text { Students feel comfortable about } \\
\text { their daily life routine }\end{array}$ & 0 & 0 & 10.0 & 72.1 & 17.9 & 4.08 & 4.00 & 0.52 \\
\hline students get better grades & 0 & 42.8 & 17.9 & 26.9 & 12.4 & 3.09 & 2.00 & 1.09 \\
\hline $\begin{array}{l}\text { I improved my behavior with } \\
\text { friends }\end{array}$ & 0 & 0 & 7.5 & 62.7 & 29.9 & 4.22 & 4.00 & 0.57 \\
\hline I'm good problem solver & 0 & 48.3 & 8.0 & 14.4 & 29.4 & 3.25 & 2.00 & 1.32 \\
\hline I'm satisfied from my academic life & 17.4 & 17.9 & 17.9 & 35.3 & 11.4 & 3.05 & 4.00 & 1.30 \\
\hline $\begin{array}{l}\text { I always give happy mood to my } \\
\text { school fellows }\end{array}$ & 0 & 0.5 & 12.9 & 47.3 & 39.3 & 4.25 & 4.00 & 0.96 \\
\hline $\begin{array}{l}\text { I effectively manage my every day } \\
\text { time }\end{array}$ & 0 & 0 & 42.8 & 52.2 & 5.0 & 3.62 & 4.00 & 0.58 \\
\hline I'm a good player & 16.9 & 42.3 & 6.5 & 27.4 & 7.0 & 2.65 & 2.00 & 1.24 \\
\hline $\begin{array}{l}\text { I give respect opinion and } \\
\text { collaboration of others }\end{array}$ & 0 & 0 & 9.0 & 73.1 & 17.9 & 4.09 & 4.00 & 0.51 \\
\hline $\begin{array}{l}\text { Students are able to set better } \\
\text { goals due to ECA }\end{array}$ & 0 & 1.5 & 13.4 & 61.7 & 23.4 & 4.07 & 4.00 & 0.65 \\
\hline $\begin{array}{l}\text { I follow rules and regulations of my } \\
\text { school }\end{array}$ & 0 & 0.5 & 12.9 & 53.2 & 33.3 & 4.19 & 4.00 & 0.67 \\
\hline $\begin{array}{l}\text { I give respect to teachers and } \\
\text { school administration }\end{array}$ & 0 & 0 & 4.5 & 48.8 & 46.8 & 4.42 & 4.00 & 0.58 \\
\hline
\end{tabular}




\begin{tabular}{|c|c|c|c|c|c|c|c|c|}
\hline I complete my homework in time & 11.4 & 38.8 & 14.9 & 24.9 & 10.0 & 2.83 & 2.00 & 1.21 \\
\hline $\begin{array}{l}\text { ECA can provide positive thinking } \\
\text { to the students }\end{array}$ & 0 & 0 & 30.8 & 39.8 & 29.4 & 3.99 & 4.00 & 0.78 \\
\hline I feel more active in my daily life & 0 & 0 & 23.9 & 64.7 & 11.4 & 3.88 & 4.00 & 0.58 \\
\hline I'm very confident in my study & 21.9 & 28.9 & 8.5 & 29.4 & 11.4 & 2.80 & 4.00 & 1.37 \\
\hline $\begin{array}{l}\text { I can control better all matter in } \\
\text { my life }\end{array}$ & 0 & 5.0 & 39.3 & 50.7 & 5.0 & 3.56 & 4.00 & 0.67 \\
\hline $\begin{array}{l}\text { ECAs have positive impact on } \\
\text { learning outcomes }\end{array}$ & 0 & 1.5 & 37.3 & 24.4 & 36.8 & 3.97 & 3.00 & 0.90 \\
\hline I avoid to sit in bad company & 0 & 0 & 8.5 & 33.3 & 58.2 & 4.50 & 5.00 & 0.65 \\
\hline $\begin{array}{l}\text { I'm participating in extra activities } \\
\text { in school }\end{array}$ & 0 & 1.0 & 43.8 & 9.5 & 45.8 & 4.00 & 5.00 & 0.97 \\
\hline I complete my assignments on time & 19.4 & 34.3 & 11.4 & 26.9 & 8.0 & 2.70 & 2.00 & 1.27 \\
\hline $\begin{array}{l}\text { I Satisfied on the activities held at } \\
\text { my school }\end{array}$ & 8.0 & 79.6 & 8.0 & 3.0 & 1.5 & 2.10 & 2.00 & 0.64 \\
\hline $\begin{array}{l}\text { I believe that extracurricular } \\
\text { activities are important in school }\end{array}$ & 0 & 0.5 & 25.4 & 63.7 & 10.4 & 3.84 & 4.00 & 0.60 \\
\hline $\begin{array}{l}\text { Can extracurricular activities helps } \\
\text { you to make new friendships? }\end{array}$ & 0 & 1.5 & 19.4 & 45.8 & 33.3 & 4.11 & 4.00 & 0.76 \\
\hline $\begin{array}{l}\text { I enjoy extracurricular activities in } \\
\text { my school }\end{array}$ & 0 & 4.5 & 35.3 & 32.3 & 27.9 & 3.84 & 3.00 & 0.89 \\
\hline $\begin{array}{l}\text { I'm confident about my success in } \\
\text { academic career }\end{array}$ & 0 & 0.5 & 27.4 & 69.7 & 2.5 & 3.74 & 4.00 & 0.50 \\
\hline ECAs disturbs studies routine & 0 & 25.4 & 48.3 & 25.4 & 1.0 & 3.02 & 3.00 & 0.74 \\
\hline $\begin{array}{l}\text { ECAs and volunteer work are the } \\
\text { part of my activities }\end{array}$ & 0 & 0.5 & 17.9 & 71.6 & 10.0 & 3.91 & 4.00 & 0.54 \\
\hline $\begin{array}{l}\text { My parents encouraged me to } \\
\text { participate extracurricular } \\
\text { program in my school }\end{array}$ & 10.0 & 43.8 & 24.9 & 19.9 & 1.0 & 2.57 & 2.00 & 0.96 \\
\hline Overall & 3.5 & 13.8 & 13.7 & 49.3 & 19.8 & 3.69 & 3.45 & 0.84 \\
\hline
\end{tabular}

Table 1 shows the finding of survey questions and the overall average of all findings that $49.3 \%$ of respondents agree with the statements of extracurricular activities (ECA) and $19.8 \%$ strongly agree, $13.7 \%$ are neutral while $13.8 \%$ respondents disagree and $3.5 \%$ strongly disagree with the statements. Average mean of the statements is 3.69 while the mode is 3.45; the average standard deviation of the statements is 0.84 . As the average mean is 3.69, its means that most of the respondents agree with the statements in the favor of ECAs.

\section{Discussion}

A students' daily life comprises lots of work and activities, among which extracurricular activities have their importance. These activities make a positive impact on students' lives by improving behavior, academic performance, and positive aspects to make adults successful and maintain traditions and skills. Students participating in extracurricular activities often benefit from better exam scores, better scores from standardized tests and diplomas, more regular class attendance, and a better self-image. While students often learn skills such as teamwork and leadership from college club activities, they reduce the likelihood of various problem behaviors. It is recommended that all educational institutions provide adequate opportunities for students to participate in extracurricular activities at the Institute facilities and outside of school hours. 
Most students recognize the importance of participating in after-school activities and alarming factors Need to raise awareness of the positive effects of participation. How to maintain a perfect balance in healthy activities and workouts. The fact that most students realize the importance of participating in extracurricular activities is an alarming factor.

Discovering the positive effects of these activities is necessary; maintaining a perfect balance between studies and these activities is mandatory to lead a prosperous and healthy life. These activities let us learn things that cannot be found in formal classes and course content (curriculum). Positive effects of extracurricular activities appear in the behavior of students.

The positive effects of extracurricular activities on students are the positive aspects of behavior, better grades, graduation, and being successful adults. Students who participate in extracurricular activities have fewer behavioral problems.

In sports, they show discipline in drills, exercises, and routines. It is your responsibility to perform these tasks correctly. If students do these assignments correctly, they will be rewarded for their good behavior and pride in their achievements. The pride they attain increases their self-esteem and confidence. This also leads to an improved status among peers. Participation in after-school activities offers students the opportunity to forge positive and voluntary ties with their school that planned remedial actions and after-school academic programs sometimes fail.

Students participating in extracurricular activities also have more self-confidence, teacher perception, and a positive attitude towards school. Students participating in extracurricular activities are less likely to drop out and are more likely to achieve higher academic achievement. Participation in extracurricular activities also reduces absenteeism and the late arrival of students. Policies like "No Pass No Play" developed by schools encourage students to keep their grades.

This prevents them from failing or dropping out. Other school rules ensure that participants avoid drug and tobacco use so that they can be disciplined and focused. Extracurricular activities also enable students to become productive learners and adults. Participating in extracurricular activities makes a student capable of skills such as leadership, teamwork, organization, analytical thinking, and problem-solving, and time management.

These activities help the student learn the skill of multitasking. This allows them to discover their talents. This kind of commitment can also help them find an interest-based job or relate their experience entering the job market to real life. After-school activities also improve pupils' social skills. Students can meet new people and work with people from different backgrounds who share common skills and interests. We must be aware of the positive impact of extracurricular activities on the educational system.

Budgets are short and extracurricular activities are expensive. Comparing the costs with the benefits of attending, many people can agree that a minimum investment is required to start a new club, activity, or team that will give benefits to students and schools (Yang, Lin \& Stomski, 2021).

\section{Conclusion}

The reviewed literature has shown similar results in terms of the benefits of participating in extracurricular activities. According to this research, it is concluded that due to ECA students feel improvement in their communication skills, feel comfortable with their routine, get better grades, improved their behavior with others like elders and friends. 
Students can be a good problem solvers, satisfy with their academic studies, always keep in a happy mood due to extra activities, effectively manage their everyday routine, be a good players, strictly follow rules and regulations of life. ECA can provide positive thinking or better personality development, be more active or more confident about their career and also avoid sitting in bad company. It was suggested that after-school activities in the school environment and local communities continue to be funded and supported. As the researchers have shown, there were many ways how participating in these structured activities could stimulate youth development. With the rise of childhood obesity, participation in physical activity is encouraged not only for the active body but also to reduce stress and provide the opportunity to collaborate with other useful and active adults. Many schools face difficult economic problems and short budgets in some societies. While some believe that reducing or eliminating extra-curricular activities can improve the budget, this is not an easy decision as other people believe these budget cuts will do more harm to the student's social and physical life. So the parents should encourage their children to participate the extracurricular activities in the schools or out of the school.

\section{Acknowledgment}

The completion of this paper cannot be separated from the assistance of all people, both direct or indirect. On this occasion, the author would like to thanks all those who helped me in writing this article, especially the editorial board of this journal who helped me to reviewed and provided suggestions for the improvement of this article and then give me a chance for published it in this edition and make it worthy. May God give rewards and helps them all.

\section{References}

Eccles, J. (2003). Extracurricular activities and adolescent development. Journal of Social Issues, 59(4),865-889.

Gardner et al, (2008). Adolescents' participation in organized activities and developmental success 2 and 8 years after high school: Do sponsorship, duration and intensity matter? Developmental Psychology; 44(3):814-30.

Gilman, (2004). Structured extracurricular activities among adolescent findings and implications for school psychologists. Psychology in the Schools ;41(1):4-9. The case for high school activities. National Federation of State High School Association. [Cited2016 May 17] <Retrieved from: www.nfhs. org/case.htm>

Himelfarb, I., Lac, A., \&Baharav, H. (2013). Examining school-related delinquencies, extracurricular activities, and grades in adolescents. Educational Studies, 40(1), 81-97. doi: 10.1080/03055698.2013.821941

Howard, A. K., \& Ziomek-Daigle, J. (2009). Bonding, Achievement, and Activities: School Bonding, Academic Achievement, and Participation in Extracurricular Activities. Georgia School Counselors Association Journal, 16(1), 39-48.

Kanar, A., \& Bouckenooghe, D. (2021). The role of extracurricular activities in shaping university students' employment self-efficacy perceptions.Career Development International, 26(2), 158-173. doi: 10.1108/cdi-02-2020-0036

Lunnenburg, D. (2010). Multiple Perspectives on Student Learning, Engagement, and Motivation in High School Biology Labs. The High School Journal, 96(3), 232-252. doi: 10.1353/hsj.2013.0010 
Mangino, W. (2014). The Negative Effects of Privilege on Educational Attainment: Gender, Race, Class, and the Bachelor's Degree. Social Science Quarterly, 95(3), 760-784. doi: $10.1111 /$ ssqu. 12003

Ramey, H., Lawford, H., \& Rose-Krasnor, L. (2019). Psychological Engagement and Behavioral Activity Participation As Predictors of Positive Youth Development. Journal Of Youth Development, 14(3), 88-109. doi: 10.5195/jyd.2019.769

Shivendra Pratap Singh, S., \& Dr. Ali Imam, D. (2012). Effect of Gender, Participation in Extracurricular Activities, Location of Schools and School Resources on Mathematics Achievement of Secondary School Students. International Journal of Scientific Research, 2(7), 124-128. doi: 10.15373/22778179/july2013/4

Slater, A., \& Tiggemann, M. (2014). Media Exposure, Extracurricular Activities, and Appearance-Related Comments as Predictors of Female Adolescents' SelfObjectification. Psychology of Women Quarterly,39(3), 375-389. doi: $10.1177 / 0361684314554606$

Yang, C., Lin, X., \&Stomski, M. (2021). Unequally Safe: Association Between Bullying and Perceived School Safety and the Moderating Effects of Race/Ethnicity, Gender, and Grade Level. School Psychology Review, 1-14. doi: 10.1080/2372966x.2020.1860427 